\title{
Impact of chronic cadmium exposure at environmental dose on escape behaviour in sea bass (Dicentrarchus labrax L.; Teleostei, Moronidae)
}

\author{
Karine Faucher $^{a,{ }^{*}}$, Denis Fichet ${ }^{b}$, Pierre Miramand ${ }^{b}$ and Jean-Paul Lagardère ${ }^{a}$
}

\author{
${ }^{a}$ Centre de Recherche sur les Ecosystèmes Littoraux Anthropisés, UMR 6217, CNRS-Ifremer-ULR, B.P. 5, 17137 \\ L'Houmeau, France \\ ${ }^{\mathrm{b}}$ Centre de Recherche sur les Ecosystèmes Littoraux Anthropisés, UMR 6217, CNRS-Ifremer-ULR, Avenue \\ Michel Crépeau, 17042 La Rochelle, France
}

*: Corresponding author : F. Faucher, email address : kfaucher@hotmail.fr

\begin{abstract}
:
The effect of chronic exposure to a low concentration $(0.5 \mu \mathrm{g} \mathrm{I}-1)$ of cadmium ions was investigated on escape behaviour of sea bass, Dicentrarchus labrax, using video analysis. Observations were also performed on the microanatomy of lateral system neuromasts. When fish were exposed for $4 \mathrm{~h}$ per day over 8 days to the cadmium ions, most of both types of neuromasts observed remained intact. However, some of them presented damaged sensory maculae. Whereas before cadmium exposure, fish responded positively to nearly all the lateral system stimulations, after exposure they decreased by about $10 \%$ their positive responses to stimulations. From the 15th day after the beginning of cadmium exposure, neuromasts presented progressively less damage, cadmium accumulation in gills and scales decreased significantly and fish escape behaviour had recovered. This study presents a new concept in ecotoxicology: using behavioural change to reveal the effects of pollution levels, scarcely detectable by currently used techniques (physiological responses).
\end{abstract}

Cadmium exposure involved a significant bioaccumulation in fish scales, slight damage to the lateral line system and a significant decrease in fish escape behaviour.

Keywords: Fish lateral system; Neuromast; Chronic cadmium exposure; Escape behaviour; Bioaccumulation

\section{Introduction}


In French coastal ecosystems, a significant number of contaminants are

51 present, particularly metal ions (Chiffoleau et al., 1999; Boutier et al., 2000). Yet, many

52 such affected coastal areas constitute nurseries, essential habitats for juvenile fish.

53 Originating from the discharge of waste, specialized industries or mining activities,

54 these pollutants are thought to be responsible for the reduction of fish resources in estuaries and coastal waters (Cole, 1979; Waldichuk, 1979). In order to protect aquatic wildlife, it is therefore necessary to determine contamination levels. In this way, water

57 quality criteria have been established, based primarily on bioaccumulation in mollusc

58 and crustacean organs (Cole, 1979; Wald ichuk, 1979 for review) or on acute lethality

59 tests (Eisler and Hennekey, 1977; Voyer et al., 1979; Hollis et al., 1999, 2000).

60 However, one aim of aquatic toxicology is to reveal the subtler and more insidious

61 changes induced by pollutants on aquatic organisms and their environment (Larsson et

62 al., 1985). According to Atchinson et al. (1987), tests based on standard acute-toxicity

63 assays $\left(\mathrm{LC}_{50}\right.$ : concentration of the toxic substance that is lethal to $50 \%$ of individuals

64 after a specific exposure time) and chronic-toxicity tests based on either full or partial

65 life cycles, or on early life stages (LOEC: lower observed effect concentration), are less

66 sensitive than behavioural studies. Behaviour is obviously a very important organism-

67 level response that is the result of molecular, physiological and ecological processes

68 (Scott and Sloman, 2004; Weis, 2004). According to Scott and Sloman (2004),

69 behaviour may hence be useful for studying environmental-pollutant effects because it

70 can provide a bioassay to determine an "ecological death" that may occur after much

71 lower exposures to the toxicant. These authors also argued that fish are an excellent

72 model in this regard, since man y ecologically relevant fish behaviours are easily

73 observed and quantified in a controlled setting. Even if fish are not overtly harmed by a 
74 contaminant, they may be unable to function in an ecological context if their normal

75 behaviour is altered (Bruslé and Quignard, 2004). Indeed, behavioural reactions may

76 occur at concentrations significantly less than those producing gross physiological

77 effects or death (Jensen and Bro-Rasmussen, 1992; Baker and Montgomery, 2001).

78 Behavioural consequences may include: 1) impaired predatory behaviour resulting in

79 poor diet, which can cause reduced growth and longevity; 2) altered pred ator-avoidance

80 behaviour; or 3) impaired schooling leading to increased mortality and / or altered

81 reproductive function (Weis, 2004). All these behavioural events form an important part

82 of a successful adaptive life history strategy. Altered behaviours caused by exposure to

83 pollutants may hence cause serious risks to the success of fish populations and disrupt

84 aquatic communities (Scott and Sloman, 2004). These authors underline that more

85 research is required concerning the impact of chronic exposure to low toxicant

86 concentrations on fish behaviours.

87 In fish, the lateral line system is involved in many behavioural events such as

88 predator and prey detection (Hoekstra and Janssen, 1986; Montgomery, 1989; Janssen

89 et al., 1999), rheotaxis (Montgomery et al., 1997; Northcutt, 1997; Baker and

90 Montgomery, 1999a, b; Coombs et al., 2001), obstacle avoidance (Blaxter and Batty,

91 1985) and intraspecific interactions (Partridge and Pitcher, 1980). The functional units

92 of this lateral line system are mechanoreceptors, the neuromasts, distributed on the

93 head, trunk and tail of the fish (Coombs et al., 1989). The morphological and functional

94 integrity of these mechanoreceptors thus appears indispensable for the existence and the

95 survival of a fish species in an ecosystem. Among metal ions, cadmium is considered as

96 the most toxic ion after mercury because concentrations leading to death are much

97 lower than for other metal ions (Eisler and Hennekey, 1977). Also, in contrast to several 
98

99

101

102

103

104

105

106

107

108

109

110

111

112

113

114

115

116

117

118

119

121

metal ions (cobalt, copper, iron, zinc, etc.), the cadmium ion has no known metabolic role and does not seem to be biologically essential or beneficial to metabolism (Friberg et al., 1974; Bryan, 1979). Given that cadmium is a calcium antagonist at the level of the gills (Verbost et al., 1987, 1988), and that calcium ions play a preponderant role in signal transduction mechanisms in neuromast hair cells in the fish lateral line system (Sand, 1975; Hudspeth and Corey, 1977; Jørgensen, 1984), cadmium ions might affect mechanoreception and thereby alter the behaviour of fish exposed to them. Several studies carried out mainly in freshwater, reported the impact of metal ions on the fish sensory system and the consequences for behaviour (see Atchinson et al., 1987 for review). For example, Baker and Montgomery (2001) showed that cadmium ions were responsible for impaired olfactory function and altered rheotaxis behaviour associated with damage to the lateral line system in freshwater fish. Very few studies, to date, have been performed on the effect of cadmium exposure on marine fish behaviour. A previous study (Faucher et al., 2006) showed that when sea bass were submitted to acute cadmium exposure at low concentration (4 hours at $0.5 \mu \mathrm{g} . \mathrm{l}^{-1}$, which represents the maximal cadmium concentration encoun tered in con taminated French estuaries), neither alteration in neuromast tissue, nor an y behavioural modification could be detected. In contrast, after an acute cadmium exposure at 10-fold higher concen tration, severe neuromast tissue damage was observed, contributing to a decrease in their escape behaviour by about $56 \%$. This escape behaviour is induced by the detection of hydrodynamic stimuli from predator displacements that act on fish lateral line system in association with their inner ear (Coombs et al., 1989).

The aim of this study has been to determine the impact of chronic lowconcentration cadmium exposure on the fish escape response. A major innovation in the 
122 present study is the determination of cadmium effects over a long time span (chron ic

123 exposure) at a concentration close to that measured in the fish's more polluted habitats

$124\left(0.5 \mu \mathrm{g} .1^{-1}\right)$ on the lateral line system of sea bass Dicentrarchus labrax. In addition, this

125 work combines for the first time data concerning accumulation of cadmium in tissues,

126 sensory tissue damage on both types of neuromasts of the lateral line and consequences

127 on fish-escape behaviour.

128

129 2. Material and methods

130

131

2.1. Experimental fishes

132

133 Experimental sea bass were obtained from the Ferme des Balein es, Ile de Ré,

134 France. They were placed in 400-1 seawater tanks at constant temperature $\left(18^{\circ} \mathrm{C}\right)$ for

135 three months with a natural photoperiod. They were fed twice a week with commercial

136 pellets. The experiments took place between June and September 2005. They were

137 carried out in two identical sets realized simultaneously, each one consisting of twelve

138 fish (about $6 \mathrm{~g}$ and $7 \mathrm{~cm}$ standard length).

139

140

2.2. Experimental set up

141

142 Experiments took place in two 40 l-tanks $(100 \times 40 \times 10 \mathrm{~cm})$ of seawater at

143 constant temperature $\left(18{ }^{\circ} \mathrm{C}\right)$. The photoperiod was controlled (14-L: $\left.10-\mathrm{D}\right)$ and an

144 automatic feeder delivered food each day, about thirty minutes after the beginning of the 
145 light phase. Fish were placed for one week in the tanks before the beginning of the

146 experiment.

147 In order to test the function or the dysfunction of their lateral line system, the

148 same set up was u sed as that previously employed (Faucher et al., 2006) to study the

149 impact of acute cadmium exposure on the trunk lateral line neuromasts and

150 consequences on the fish behaviour. A pipette connected to a hand-operated syringe was

151 used to inject a water jet between the water surface and the base of the tank when fish

152 swam in the vicinity (about $5 \mathrm{~cm}$ ) of the pipette. Each day, three stimulations (injection

153 of a water jet) were performed and the fish responses were recorded with an analog

154 video camera (SONY CCD-VX1E Handicam Pro, 25-frames. $\mathrm{s}^{-1}$ ) positioned at a height

155 of $\sim 1 \mathrm{~m}$ above the water surface. The lateral line system of the fish was considered as

156 functional when the water jet stimulation provoked a sudden escape reaction,

157 characterised by the bending of the fish's body in to a C-like shape, followed by an

158 abrupt swimming acceleration away from the initial location (see Faucher et al., 2006).

159 Such a response was counted as a positive response and noted as 1 . Immobility or a

160 constant swimming velocity was noted as null response and noted as 0 (see Faucher et

161 al., 2006 for illustrations). Each day, the number of positive responses out of the three

162 expected was calculated. In this way, sea bass were recorded each day under control

163 conditions for three weeks.

164

165 2.3. Cadmium exposure

166

167 To reveal the impact of chronic cadmium exposure on the lateral line system

through its consequences on escape responses, two sets of experiments with two 
169 separate groups of fish were performed simultaneously. First, fish response was

170 recorded under control condition s every day for 3 weeks. Then, each day for 8 days, sea

171 bass were collected and placed for $4 \mathrm{~h}$ (the time need ed for cadmium adsorption onto a

172 particle, Chiffoleau et al., 1999) in a 10 l-tank of seawater to which $0.5 \mu \mathrm{g} . \mathrm{l}^{-1}$ cadmium

$173\left(\mathrm{Cd}\left(\mathrm{NO}_{3}\right)_{2}\right.$, Merck, cadmium standard solution $1000 \mathrm{mg} . \mathrm{l}^{-1}$ in nitric acid $\left.0.5 \mathrm{M}\right)$ had

174 been added. This intermittent exposure for $4 \mathrm{~h}$ per day during 8 consecutive days in

175 another tank was chosen instead of 8 continuous days in the experimental tank to avoid

176 the risk that cadmium ions might destroy the biological filtration system in the

177 experimental tank. The concentration tested represents the maximal cadmium

178 concentration encountered in highly polluted estuaries such as the Gironde, Scheldte

179 and Hudson estuaries (Klinkhammer and Bender, 1981; Elbaz-Poulichet et al., 1987;

180 Jouanneau et al., 1990). Such an intermittent cadmium exposure may occur in natural

181 estuaries when fish cross through maximum turbidity zone where sediments are known

182 to adsorb contaminated particles as metal ions (Jouanneau et al., 1990; Chiffoleau et al.,

183 1999). Fish were then placed back in their experimental tank. Their swimming

184 behaviour was normal. After allowing several hours for recovery, the time required for

185 the entire dis appearance of the stress caused by cadmium exposure, the sea bass

186 responses to the three daily stimulations by the water jet were recorded, every day until

187 the restoration of a normal behaviour.

188 To evaluate the stress caused by daily manipulations, two placebo treatments

189 (4-hour baths in seawater without cadmium) were performed one week apart during the

190 three weeks of recording under control conditions. 


3

\subsection{Water contamination analyses}

To determine the cadmium concentration to which the fish were really exposed each day during the 4 hours of exposure, sample water was collected at 0,2 and 4 hours after the addition of $0.5 \mu \mathrm{g} .1^{-1}$ cadmium, on the $6^{\text {th }}, 7^{\text {th }}$ and $8^{\text {th }}$ day of exposure. Samples collected at each time $(0,2$ and $4 \mathrm{~h})$ from the $6^{\text {th }}, 7^{\text {th }}$ and $8^{\text {th }}$ day were taken to constitute a "0h" sample, a "2h" sample and a "4h" sample. Analyses of cadmium concentration in these three water samples were performed in the Institut Pasteur of Lille. Water samples were filtered through $0.45 \mu \mathrm{m}$, and cadmium concentration measurements were realized using ion-adsorption onto resin.

\subsection{Metal analyses}

(1)

To evaluate metal tissue contamination, gills and scales covered by mucus were collected from three fish sampled simultaneously: in control conditions, and on the $3^{\text {rd }}$ day, the $8^{\text {th }}$ day, the $15^{\text {th }}$ day ( 8 days of exposure followed by 7 days of depuration) and the $21^{\text {st }}$ day ( 8 days of exposure followed by 13 days of depuration) after the beginning of cadmium exposure. Fish gills and scales were chosen because they are in direct contact with pollutants and thus might represent short-term biomarkers of contamination compared to the long-term contamination biomarkers (liver, kidney) usually used. Tissue samples were dried at $50^{\circ} \mathrm{C}$ for 2 days. Dry samples were weighed and digested for 2 days in $5 \mathrm{ml}$ concentrated $(14 \mathrm{~N})$ nitric acid at $80^{\circ} \mathrm{C}$ until the digestion was completed, then heated to dryness. $2 \mathrm{ml} 0.3 \mathrm{~N}$ nitric acid was then added. Three analytical blanks were prepared in a similar manner without samples to check for 
216 possible contamination. Corrections were applied wherever necessary. The digestion

217 procedure was also applied to standards (200 mg of DORM-1: dogfish muscle powder)

218 of Cd concentrations to check the spectrophotometer calibration. Metal concentrations

219 were then measured with an atomic absorption spectrophotometer (HITACHI, Polarized

220 Zeeman Atomic Absorption Spectrophotometer Z-5000). The results for the standard

221 reference materials were in good agreement with the certified values reported $(2.56 \%$

222 deviation). All glassware was carefully decontaminated with acid (3.5\% nitric acid,

223 Merck + $5 \%$ fuming hydrochloric acid, Merck) for 24 hours and was then copiously

224 rinsed with distilled water before any new use. The experiment was conducted in

225 triplicate and the reported values are an average of the three values measured in tis sue

226 of the three fish collected in control conditions, on the $3^{\text {rd }}$ day, the $8^{\text {th }}$ day, the $15^{\text {th }}$ day

227 and the $21^{\text {st }}$ day after the beginning of cadmium exposure. Results are expressed as the

228 metal concentration in $\mu$ g reported on a dry weight basis.

2.6. Observation of lateral line system tissue status

For each set of experiments, to verify the tis sue status of both superficial and

canal lateral line system neuromasts in sea bass after cadmium exposure, four batches of

twelve fish (three taken on each date) were collected. The first batch, sampled on the $3^{\text {rd }}$

day af ter cadmium exposure, the second at the end of the period of chronic cadmium

exposure (the $8^{\text {th }}$ day), the third batch on the $15^{\text {th }}$ day, and the last batch sampled on the

$23721^{\text {st }}$ day after the beginning of chronic cadmium exposure. The neuromast tissue status

238 of cadmium-exposed fish was compared with that of two control fish collected from

239 each experimental tank after three weeks of recording under control conditions. Prior to 
240 sacrifice, collected fish were anaesthetised with $75 \mathrm{mg} .1^{-1}$ MS -222 (3-aminoben zoic acid

241 ethyl, Sigma) for about 15 minutes. The whole of trunk lateral line mechanoreceptors

242 was then sampled. Tissue samples were prepared for scanning electron microscope

243 observations following the same set up as in Faucher et al. (2003).

244

245

\subsection{Statistical analyses}

246 average number of superficial and canal neuromasts damaged per scale was counted.

249 Data obtained were then compared between fish exposed to cadmium and control fish using $\chi^{2}$-tests.

Cadmium accumulation data in fish gills and scales were examined with a two-

252

To estimate damage caused by cadmium to both types of neuromasts, the alysis of variance (ANOVA) with organ (gills and scales) and exposure time (control, 3, 8, 15 and 21 days) as dependent variables, after finding homogeneity of variances $(p>0.05)$. Significant main effects were followed up with Student-NewmanKeuls post-hoc tests.

Behavioural responses to water jet stimulations were analysed following the same data treatment as in Faucher et al. (2006). Data obtained are expressed as the average percentage of positive responses $\overline{\mathrm{P}_{\mathrm{k}}} \pm \mathrm{SD}$ (standard deviation of the mean). The number of data points obtained each day with the two sets of experiments is indicated between brackets. The percentages obtained before and after cadmium exposure were compared using $\chi^{2}$-test.

All statistical analyses were performed with the statistical softwares XISTATPro 6.0 and Minitab 13.0. The level of significance was set at $p<0.05$. 


\section{Results}

Water analyses showed that sea bass were exposed to an average concentration

of dissolved cadmium ions in seawater of $0.48 \pm 0.18 \mu \mathrm{g} .1^{-1}(\mathrm{n}=3)$ during the four

hours of exposure. For all the duration of the experiment, fish mortality was null.

270

\subsection{Effects of cadmium exposure on sea bass lateral line system}

272

273

274

275

276

277

278

279

280

281

Compared to control fish (Fig. 1A and B), the majority of superficial (Fig. 1C) and canal (Fig. 1D) neuromasts of sea bass exposed to $0.5 \mu \mathrm{g} .1^{-1}$ for three days, did not present any apparent tissue damage. The majority of them possessed intact sensory maculae: hair bundles of subjacent sensory hair cells were well developed. However, some seemed to be slightly damaged (Fig. 1E and F): their hair cell bundles were sparse, shortened, and sometimes not visible. Although the percentage of superficial neuromasts damaged $(8.6 \%, \mathrm{n}=35)$ was not significantly different from that in control fish for which all neuromasts were intact $\left(0 \%\right.$ destroyed, $\mathrm{n}=19, \chi^{2}=2.515, \mathrm{p}=$ $0.113)$, the percentage of canal neuromasts damaged $(27.8 \%, \mathrm{n}=18)$ after three days of cadmium exposure was significantly greater than in control fish $\left(0 \%, \mathrm{n}=12, \chi^{2}=\right.$ 4.623, $\mathrm{p}=0.032)$. At the end of the period of chronic cadmium exposure ( 8 days $)$, fish presented mainly intact superficial (Fig. 2A) and canal neuromasts (Fig. 2B). However, some of them were nevertheless damaged as illustrated by the figure $2 \mathrm{C}$ and $\mathrm{D}$. The percentage of superficial neuromasts altered $(6.3 \%, \mathrm{n}=24)$ was not significantly different from that in control fish $\left(0 \%, \mathrm{n}=19, \chi^{2}=1.709, \mathrm{p}=0.191\right)$. In contrast, the 
288 percentage of canal neuromasts damaged $(30.8 \%, \mathrm{n}=13)$ remained higher than that 289 observed in control fish $\left(0 \%, \mathrm{n}=12, \chi^{2}=4.719, \mathrm{p}=0.030\right)$. Then, 15 days after the 290 beginning of cadmium exposure, superficial (Fig. 3A) and canal (Fig. 3B) neuromasts 291 were still mainly intact. A small percentage of superficial $(4.8 \%, \mathrm{n}=21)$ and canal $292(22.2 \%, \mathrm{n}=9)$ neuromasts were once again damaged (Fig. 3C and D) but less markedly 293 than previously. The percentage of neuromasts altered by cadmium exposure was not 294 significant compared to that observed in control fish, whether in the case of superficial $295\left(\chi^{2}=1.267, \mathrm{p}=0.260\right)$ or canal neuromasts $\left(\chi^{2}=3.159, \mathrm{p}=0.076\right)$. As before, at the 296 end of the experiment (21 days after the beginning of cadmium exposure), nearly all the

297 neuromasts of each type were intact (Fig. 4A and B). Nevertheless, some superficial $298(5.6 \%, \mathrm{n}=18)$ and canal $(16.7 \%, \mathrm{n}=6)$ neuromasts remained slightly altered (Fig. 4C 299 and D): their hair bundles seemed to be a little sparse or shortened. However, the 300 percentage of damaged neuromasts was not significantly greater than in control fish $\left(\chi^{2}\right.$

$301=1.413, \mathrm{p}=0.235$ for superficial and $\chi^{2}=2.094, \mathrm{p}=0.148$ for canal neuromasts). It is 302 relevant to note that the percentages of damaged neuromasts and their tissue alteration 303 (hair bundles almost non visible) were maximal between 3 and 8 days after exposure. 304 Indeed, no significant difference was observed in the case of the percentage of damaged 305 superficial $\left(\chi^{2}=0.096, \mathrm{p}=0.757, \mathrm{n}=59\right)$ and can al neuromasts $\left(\chi^{2}=0.018, \mathrm{p}=\right.$ $3060.894, \mathrm{n}=31$ ) between 3 and 8 days after the beginning of cadmium exposure. 307

\subsection{Cadmium bioaccumulation}

309

Figure 5 shows the $\mathrm{Cd}$ accumulation as a function of exposure time. For gills

311 (Fig. 5A) as for scales (Fig. 5B), average cadmium concentrations measured in control 
312 fish were relatively high: $0.054 \pm 0.032 \mu \mathrm{g} \cdot \mathrm{g}^{-1}$ of dry weight $(\mathrm{n}=3)$ in gills and $0.052 \pm$

$3130.005 \mu \mathrm{g} \cdot \mathrm{g}^{-1}$ of dry weight $(\mathrm{n}=3)$ for scales. In fish gills, cadmium ions did not seem to

314 accumulate significantly $\left(\mathrm{F}_{4,15}=0.760, \mathrm{p}=0.574, \mathrm{n}=15\right)$. In contrast, for the whole

315 duration of experiment, the average concentration of cadmium in fish scales was

316 significantly greater than that in gills $\left(\mathrm{F}_{2,30}=13.811, \mathrm{p}=0.001, \mathrm{n}=30\right)$. The maximal

317 concentration in cadmium was observed in scales after 3 days of exposure and was

$3180.147 \pm 0.015 \mu \mathrm{g} \cdot \mathrm{g}^{-1}$ dry weight $(\mathrm{n}=3)$. This concentration of cadmium in scales after 3

319 days of exposure was significantly higher than that measured in control fish $(\mathrm{t}=5.856$,

$320 \mathrm{p}<0.0001, \mathrm{n}=6)$, and after 8 days $(\mathrm{t}=4.874, \mathrm{p}=0.001, \mathrm{n}=6), 15$ days $(\mathrm{t}=4.434, \mathrm{p}=$

$3210.001, \mathrm{n}=6)$ and 21 days $(\mathrm{t}=6.329, \mathrm{p}<0.0001, \mathrm{n}=6)$. Then, cadmium concentration

322 in scales tended to decrease to be not significantly different from that measured in

323 control fish $\left(\mathrm{F}_{3,12}=1.273, \mathrm{p}=0.348, \mathrm{n}=12\right)$.

324

325

3.3. Consequences of cadmium exposure on fish responses to the water jet

326

327

During the three weeks of recording under control conditions, sea bass

328

responded positively at $94.05 \pm 8.88 \%(n=42)$ : they swam away after stimulation by

the water jet (Fig. 6). The two placebo treatments realised did not generate any

330

significant behavioural modification in fish. The day of cadmium exposure, the average

331 positive response percentage fell significantly $\left(\chi^{2}=6.290, \mathrm{p}=0.012\right)$ : sea bass

332 responded positively in only $66.67 \pm 0.00 \%(n=2)$ of stimulations. From day 1 and

333 during all the cadmium exposure period (8 days), this average positive response

334 percentage progressively decreased from $100.00 \pm 0.00 \%(n=2)$ to $66.67 \pm 0.00 \%$ (n

$335=2$ ). Until the $15^{\text {th }}$ day ( 8 days of exposure followed by 8 days of depuration), 
336 cadmium-treated fish went on being significantly les s reactive to stimulation by the

337 water jet than control fish: they presented an average response percentage of $84.17 \pm$

$33815.22 \%\left(\mathrm{n}=30, \chi^{2}=5.284, \mathrm{p}=0.022\right)$. Then, from the $15^{\text {th }}$ day, fish started to

339 positively respond again to stimulations in $95.56 \pm 7.63 \%(n=15)$ of cases. From this

340 day, the average percentage positive response was no longer significantly different from

341 that recorded in control conditions $\left(94.05 \pm 8.88 \%, \mathrm{n}=42, \chi^{2}=0.168, \mathrm{p}=0.682\right)$.

342

All results obtained in this study are summed up in the figure 7. In summary,

344 cadmium exposure involved: 1) a significant cadmium bioaccumulation in scales, 2)

345 slight damages to both types of neuromasts, can al neuromasts being the more altered,

346 and 3) a sign ificant decrease in fish escape behaviour during the time of exposure. After

347 this time, fish tended to restore their escape behaviour in association with a regeneration

348 of neuromasts tissue and a cadmium depuration in gills and scales.

\section{Discussion} ecologically relevant monitoring of environmental contamination (reviewed by

354 Atchinson et al., 1987). We have now done this for chronic cadmium exposure in sea bass, Dicentrarchus labrax, at the concentration occurring in situ in polluted French estuaries.

In a previous study, Faucher et al. (2006) showed that $48 \mathrm{~h}$ after 4 hours 0.5 $\mu \mathrm{g} .1^{-1}$ acu te cadmium exposure, neither type of neuromasts presented any apparent tissue damage. In the present study, after 3 days of similar exposure, some neuromasts 
360 of both types (at most $8.6 \%$ for superficial and $30.8 \%$ for canal neuromasts) were

361 damaged by cadmium ions. Three days of in termittent $0.5 \mu \mathrm{g} .1^{-1}$ cadmium exposure

362 might thus be the threshold period needed to affect sea bass lateral line system tis sues.

363 This hypothesis is reinforced by our other results: the maximum cadmium

364 bioaccumulation in fish scales and major behavioural consequences were also measured

365 after three days of exposure.

366 Before chronic cadmium exposure, gills and scales from control fish already

367 presented a relatively high amount of cadmium, as previously found in the black goby

368 Gobius niger (Migliarini et al., 2005) and in the juvenile olive flounder Paralichthys

369 olivaceus (Kim et al., 2004). This may be due to previous cadmium exposures of the

370 fish during the course of their life. Sea bass used in this study were obtained from a

371 commercial source located in Ile de Ré, an island located on the west coast of France

372 and known for its relatively high concentration of dissolved cadmium ions in seawater

373 (Boutier et al., 2000). Cadmium concentrations measured in gills and scales of control

374 fish corresponded thus to the background. Nevertheless, bioaccumulation data ob tained

375 showed that after exposure, cadmium accumulated much more in fish scales than in

376 gills. It is hence relevant to note that fish scales might be a pollutant marker more

377 sensitive than gills which have been commonly used until now. This suggestion is

378 supported by the observation of the adverse effect of cadmium on the morphology

379 (Yoshitomi et al., 1998) and the structural aspect (Rishi and Jain, 1998) of freshwater

380 fish scales. Rishi and Jain (1998) argued that fish scales could thus be used as a

381 biomarker of pollution, particularly as these can be used without sacrificing the animal.

382 In vitro, it has been also demonstrated that cadmium influenced osteoclastic activities

383 after acute exposure and inhibited osteoblastic activities under long-term exposure 
384 (Suzuki et al., 2004). Moreover, our results showed that after a maximum at three days,

385 cadmium accumulation tended to decrease. The fact that fish accumulate less cadmium

386 in their scales after 8 days of exposure could be explained by the action mechanism of

387 cadmium ions on cells. Cadmium and calcium ions are known to be mutually

388 antagonistic in their fixation on sites located at the gills (Verbost et al., 1987, 1988).

389 Given that the lateral line system functions through calcium ion flux, we suggest that

390 cadmium may block the $\mathrm{Ca}^{2+}$-ATPase pump of the baso-lateral membrane of neuromast

391 hair cells. The result would be a blocking of calcium transport in cells associated with

392 their clearly observed degeneration. One could hypothesise that, as the cells degenerate,

393 fixation sites become less available to cadmium ions and the consequence could be less

394 measured cadmium accumulation in the tissue. This hypothesis corroborates Migliarini

395 et al.'s (2005) speculation that cadmium ions fix to binding sites on the gills until they

396 are totally occupied. Yet, fish gills and scales are thought to be usually covered by

397 mucus that protects for the skin and the sensitive gill epithelium against xenobiotics

398 such as metal ions (Pawert et al., 1998; Bruslé and Quignard, 2004). However, at least

399 in the present work, mucus appeared not to protect much against metal ions such as

400 cadmium, since at least a few of both types of neuromasts were damaged by cadmium.

401 Cadmium ions must have passed across the mucus layer and damaged sensory hair cell

402 bundles of the fish lateral line system, in spite of the low-concentration of cadmium

403 applied. This result, combined with those obtained with fish lateral line systems

404 exposed to acute high concentration of cadmium (Faucher et al., 2006), refutes the

405 proposal of Døving (1991) that the lateral line organs are shielded from direct pollutant

406 exposure by a set of supporting cells and by their gelatinous cupulae. Our results show

407 that, in contrast to Hudspeth's (1983) and Døving's (1991) hypotheses, 
408 mechanoreceptors of the lateral line system are not only accessible by pollutants via the 409 internal path (blood) but also by direct external exposure.

410 In our experiments, the behavioural consequence of alteration of the lateral line 411 system by cadmium ions was a decrease in fish escape responses by about $10 \%$. This 412 result is supported by some studies realized on freshwater fish showing that cadmium 413 ions can disrupt reproductive behaviour (Jones and Reynolds, 1977), agonistic 414 behaviour (Sloman et al., 2003), spawning site selection and natal homing (Baker and 415 Montgomery, 2001), predator avoidance and prey capture (Scott et al., 2003) and also 416 electroreception (Neuman et al., 1991). Our previous study had shown that when fish 417 were exposed to acute high-concentration cadmium, the sea bass lateral line system 418 regenerated itself after about twenty-one days (Faucher et al., 2006). In this study, about 419 fifteen days were necessary after the beginning of the chronic low-concentration 420 cadmium exposure for fish to show a progressive restoration of their escape behaviour.

421 In parallel, at this time, the tissues of both types of neuromasts presented progres sively 422 less damage compared to observations realized during high-cadmium exposure. We can 423 thus conclude that, after such a chronic low-concentration cadmium exposure, the 424 lateral line system needs about 15 days to regenerate itself at a sufficient rate to allow 425 full detection of hydrodynamic stimuli. After chronic exposure (for 8 days) to cadmium, 426 regeneration of both types of neuromasts proved to be quicker than Faucher et al. (2006) 427 found after acute exposure (for only 1 day) to 10-fold higher concentration cadmium. 428 This shorter time needed for neuromasts to regenerate is likely because, in the present 429 study, few neuromasts of both types were entirely destroyed whereas after the acute 430 exposure to high-concen tration cadmium, all superficial canal neuromasts were totally 431 destroyed. 
To test the sea bass lateral line system function, the stimuli applied in this study were relatively strong, probably more intense than signals received by fish when a

434 predator or a prey approaches. In this way, if sea bass exposed to this low concentration 435 of cad mium responded less frequently (reduction by $10 \%$ ) to strong stimuli, it is likely 436 that reaction to the weaker stimuli characteristic of their natural environment would be

437 reduced relatively even more markedly. Even if the tis sues of their neuromasts remained 438 normal in aspect, lower efficiency is likely in the detection of potential predators or prey 439 in natural environments after exposure to cadmium. To confirm or refute this

440 hypothesis, the lateral line system response to variable intensity stimuli would have to 441 be tested by varying the current velocity of stimulations, attempting to approach as far 442 as possible the range of stimuli generated by moving prey. In addition, in French 443 estuaries, fish are permanently exposed to a mixture of metal ions $(\mathrm{Ag}, \mathrm{Cd}, \mathrm{Co}, \mathrm{Cu}, \mathrm{Hg}$,

$444 \mathrm{Ni}, \mathrm{Pb}, \mathrm{Zn}$, etc.), it would hence be relevant to examine whether there exists any 445 synergy or antagonism among these different metal ions on fish lateral line systems 446 inducing consequences for fish behaviour and for the survival of different fish species in 447 situ.

This study has produced new data and understanding about the vulnerability of 452 the sea bass lateral line system to cadmium, and it also illustrates a new concept in 453 ecotoxicology. Although after chronic low-concentration cadmium exposure, 454 accumulation and sensory tissue damage were both relatively slight, we have clearly 455 demonstrated that such exposure leads to behavioural consequences. More behavioural 456 studies in ecotoxicology are now needed. Behaviour is an important organism trait 
457 response that may represent a pollution marker more sensitive and more relevant than

458 observations of changes in physiology or microanato my alone (Doving, 1991; Scott and

459 Sloman, 2004; Weis, 2004). Behaviour is furthermore integrated with other levels of

460 biological organization (Scott and Sloman, 2004), so it needs to be considered as a

461 predictor and a result of other internal and external biological processes such as

462 ecological and physiological indicators of toxicity.

463

464 Acknowledgements

465

466 We wish to thank Ian Jenkinson for improving our English writing. Thanks to 467 the Ferme des Baleines for providing the animals. We would also like to thank the 468 Centre Commun d'Analyses (CCA), Université de La Rochelle, for allowing the use of 469 a scanning electron microscope.

470

471 References

472 Atchinson, G.J., Henry, M.G., Sandheinrich, M.B., 1987. Effects of metals on fish 473 behavior: a review. Environ. Biol. Fish. 18(1), 11-25.

474 Baker, C.F., Montgomery, J.C., 1999a. The sensory basis of rheotaxis in the blind 475 mexican cave fish, Astyanax fasciatus. J. Comp. Physiol. A. 184, 519-527.

476 Baker, C.F., Montgomery, J.C., 1999b. Lateral line mediated rheotaxis in the antarctic 477 fish Pagothenia borchgrevinki. Polar Biol. 21, 305-309.

478 Baker, C.F., Montgomery, J.C., 2001. Sensory deficit induced by cadmium in banded 479 kokopu, Galaxias fasciatus, juveniles. Environ. Biol. Fish. 62, 455-464. 
Blaxter, J.H.S., Batty, R.S., 1985. Herring behaviour in the dark: responses to stationary and continuously vibrating obstacles. J. Mar. Biol. Ass. U.K. 65, 1031-1049.

Boutier, B., Chiffoleau, J.-F., Gonzalez, J.-L., Lazure, P., Auger, D., Truquet, I., 2000. Influence of the Gironde estuary outputs on cadmium concentrations in the coastal waters: consequences on the Marennes-Oléron bay (France). Oceanologica Acta. 23(7), 745-757.

Bruslé, J., Quignard, J.P., 2004. Les poissons et leur environnement - Ecophysiologie et comportements adaptatifs. TEC \& DOC Ed., Paris Lavoisier, 1522 pp.

Bryan, G.W., 1979. Bioaccumulation of marine pollutants. Phil. Trans. R. Soc. Lond. B286, 483-505.

Chiffoleau, J.-F., Gonzalez, J.-L., Miramand, P., Thouvenin, B., Guyot, T., 1999. Le cadmium: comportement d'un contaminant métallique en estuaire. Programme scientifique Seine-Aval. 10, 39 pp.

Cole, H.A., 1979. Pollution of the sea and its effects. Proc. R. Soc. Lond. B. 205, 17-30.

Coombs, S., Janssen, J., Webb, J.F., 1989. Diversity of lateral systems: evolutionary and functional considerations. In: Atema, J., Fay, R.R., Popper, A.N., Tavolga, W.N., Sensory Biology of Aquatic Animals. New York, Springer Verlag, pp. 553-593.

Coombs, S., Braun, C.B., Donovan, B., 2001. The orienting response of lake michigan mottled sculpin id mediated by canal neuromasts. J. Exp. Biol. 204, 337-348.

Døving, K.B., 1991. Assessment of animal behaviour as a method to indicate environmental toxicity. Comp. Biochem. Physiol. 100C(1-2), 247-252.

Eisler, R., Hennekey, R.J., 1977. Acute toxicities of $\mathrm{Cd}^{2+}, \mathrm{Cr}^{6+}, \mathrm{Hg}^{2+}, \mathrm{Ni}^{2+}$ and $\mathrm{Zn}^{2+}$ to estuarine macrofauna. Arch. Environ. Contam. Toxicol. 6, 315-323. 
503 Elbaz-Poulichet, F., Martin, J.M., Huang, W.W., Zhu, J.X., 1987. Dissolved Cd

504 behaviour in some selected french and chinese estuaries. Consequences on $\mathrm{Cd}$

505 supply to the ocean Mar. Chem. 22(2-4), 125-136.

506 Faucher, K., Aubert, A., Lagardère, J.P., 2003. Spatial distribution and morphological

507 characteristics of the trunk lateral line neuromasts of the sea bass (Dicentrarchus

508 labrax, L.; Teleostei, Serranidae). Brain Behav. Evol. 62, 223-232.

509 Faucher, K., Fichet, D., Miramand, P., Lagardère, J.P., 2006. Impact of cadmium

510 exposures on the trunk lateral line neuromasts and consequences on the "C-start"

511 response behaviour of the sea bass (Dicentrarchus labrax L.; Teleostei,

512 Moronidae). Aquat. Toxicol. 76(3-4), 278-294.

513 Friberg, L., Piscator, M., Nordberg, G.F., Kjells trom, T., 1974. Cadmium in the

$514 \quad$ environment. $2^{\text {nd }}$ edition, CRC Press, New-York.

515 Hoekstra, D., Janssen, J., 1986. Lateral line receptivity in the mottled sculpin (Cottus

516 bairdi). Copeia 1, 91-96.

517 Hollis, L., McGeer, J.C., McDonald, D.G., Wood, C.M., 1999. Cadmium accumulation, 518 gill Cd binding, acclimation, and physiological effects during long term sublethal

519 Cd exposure in rainbow trout. Aquat. Toxicol. 46, 101-119.

520 Hollis, L., McGeer, J.C., McDonald, D.G., Wood, C.M., 2000. Effects of long term

521 sublethal $\mathrm{Cd}$ exposure in rainbow trout during soft water exposure: implication for

522 biotic ligand modelling. Aquat. Toxicol. 51, 93-105.

523 Hudspeth, A.J., 1983. Mech anoelectrical transduction by hair cells in the

524 acousticolateralis sensory system. Annu. Rev. Neurosci. 6, 187-215. 
525 Hudspeth, A.J., Corey, D.P., 1977. Sensitivity, polarity, and conductance change in the 526 response of vertebrate hair cells to controlled mechanical stimuli. Proc. Natl.

$527 \quad$ Acad. Sci. U.S.A. 74(6), 2407-2411.

528 Janssen, J.V., Sideleva, V., Biga, H., 1999. Use of the lateral line for feeding in two

$529 \quad$ Lake Baikal sculpins. J. Fish Biol. 54, 404-416.

530 Jensen, A., Bro-Rasmussen, F., 1992. Environmental cadmium in Europe. Rev.

$531 \quad$ Environ. Contam. Toxicol. 125, 101-181.

532 Jones, J.C., Reynolds, J.D., 1997. Effects of pollution on reproductive behaviour of 533 fishes. Rev. Fish Biol. Fish. 7, 463-491.

534 Jørgensen, F., 1984. Influence of $\mathrm{Ca}^{2+}$ on the voltage-dependent mechanosensitivity of 535 the hair cells in the latera line organs of Xenopus laevis. Acta Physiol. Scand. 120, $536 \quad 481-488$.

537 Jouanneau, J.M., Boutier, B., Chiffoleau, J.F., Latouche, C., Phillips, I., 1990. Cadmium 538 in the Gironde fluvioestuarine system: behaviour and flow. Sci. Total Environ. $53997 / 98,465-479$.

540 Kim, S.G., Jee, J.H., Kang, J.C., 2004. Cadmium accumulation and elimination in 541 tissues of juvenile olive flounder, Paralichthys olivaceus after sub-chronic $542 \quad$ cadmium exposure. Environ. Pollut. 127, 117-123.

543 Klinkhammer, G.P., Bender, M.L., 1981. Trace metal distributions in the Hudson River 544 estuary. Est. Coast. Shelf Sci. 12, 629-643.

545 Larsson, Å., Haux, C., Sjöbeck, M.L., 1985. Fish physiology and metal pollution:

546 results and experiences from laboratory and field studies. Ecotoxicol. Environ.

$547 \quad$ Saf. 9, 250-281. 
548 Migliarini, B., Campisi, A.M., Maradonna, F., Truzzi, C., Annibaldi, A., Scarponi, G.,

549 Carnevali, O., 2005. Effects of cadmium exposure on tes tis apoptosis in the

$550 \quad$ marine teleost Gobius niger. Gen. Comp. Endocrinol. 142, 241-247.

551 Montgomery, J.C., 1989. Lateral detection of planktonic prey. In: Coombs, S., Görner,

552 P., Münz, H., The mechanosensory lateral line, neurobiology and evolution. New

$553 \quad$ York, Springer Verlag, pp. 561-573.

554 Montgomery, J.C., Baker, C.F., Carton, A.G., 1997. The lateral line can mediate

$555 \quad$ rheotaxis in fish. Nature. 389, 960-963.

556 Neuman, I.S.A., van Rossum, C., Bretschneider, F., Teunis, P.F.M., Peters, R.C., 1991.

557 Biomonitoring: cadmium deteriorates electro-orientation performance in catfish.

$558 \quad$ Comp. Biochem. Physiol. 100C(1-2), 259-262.

559 Northcutt, R.G., 1997. Swimming against the current. Nature. 389, 915-916.

560 Partridge, B.L., Pitcher, T.J., 1980. The sensory basis of fish schools: relative roles of

561 lateral line and vision. J. Comp. Physiol. A. 135, 315-325.

562 Pawert, M., Müller, E., Triebskorn, R., 1998. Ultrastructure changes in fish gills as

563 biomarker to assess small stream pollution. Tis sue \& Cell. 30(6), 617-626.

564 Rishi, K.K., Jain, M., 1998. Effect of toxicity of cadmium on scale morphology in

565 Cyprinus carpio (Cyprinidae). Bull. Environ. Contam. Toxicol. 60, 323-328.

566 Sand, O., 1975. Effects of different ionic environments on the mechano-sensitivity of

567 lateral line organs in the mudpuppy. J. Comp. Physiol. 102, 27-42.

568 Scott, G.R., Sloman, K.A., Rouleau, C., Wood, C.M., 2003. Cadmium disrupts

569 behavioural and physiological responses to alarm substance in juvenile rainbow

$570 \quad$ trout (Oncorhyncus mykiss). J. Exp. Biol. 206, 1779-1790. 
571 Scott, G.R., Sloman, K.A., 2004. The effects of environmental pollutan ts on complex

572 fish behaviour: integrating behavioural and physiological indicators of toxicity. A

573 review. Aquat. Toxicol. 68, 369-392.

574 Sloman, K.A., Baker, D.W., Ho, C.G., McDonald, D.G., Wood, C.M., 2003. The effects

575 of trace metal exposure on agonistic encounters in juvenile rainbow trout,

$576 \quad$ Oncorhynchus mykiss. Aquat. Toxicol. 63, 187-196.

577 Suzuki, N., Yamamoto, M., Watanabe, K., Kambegawa, A., Hattori, A., 2004. Both

578 mercury and cadmiu m directly influence calcium homeostasis resulting from the

579 suppression of scale bone cells: the scale is a good model for the evaluation of

580 heavy metals in bone metabolism. J. Bone Miner. Metab. 22, 439-446.

581 Verbost, P.M., Flik, G., Lock, R.A.C., Wendelaar Bonga, S.E., 1987. Cadmium

582 inhibition of $\mathrm{Ca}^{2+}$ uptake in rainbow trout gills. Am. J. Physiol. 253, R216-R221.

583 Verbost, P.M., Flik, G., Lock, R.A.C., Wendelaar Bonga, S.E., 1988. Cadmium inhibits

584 plasma membrane calcium transport. J. Membr. Biol. 102, 97-104.

585 Voyer, R.A., Heltsche, J.F., Kraus, R.A., 1979. Hatching success and larval mortality in

586 an estuarine teleost, Menidia menidia (Linnaeus), exposed to cadmium in constant

587 and fluctuating salinity regimes. Bull. Environm. Contam. Toxicol. 23, 475-481.

588 Waldichuk, M., 1979. The assessment of sublethal effects of pollutants in the sea.

589 Review of the problems. Phil. Trans. R. Soc. Lond. B. 286, 399-424.

590 Weis, J.S., 2004. Does pollution affect fisheries? Book critique. Environ. Biol. Fish. 00, $591 \quad 1-3$

592 Yoshitomi, T., Koyama, J., Iida, A., Okamoto, N., Ikeda, Y., 1998. Cadmium-induced 593 scale deformation in carp (Cyprinus carpio). Bull. Environ. Contam. Toxicol.

$594 \quad 60,639-644$. 
595 Figure 1: Scanning electron micrographs showing the effect of low-concentration

596 cadmium exposure (4 hours per day at $0.5 \mu \mathrm{g} .1^{-1}$ ) for 3 days on tissue status of both

597 types of neuromasts from the trunk lateral line of sea bass, Dicentrarchus labrax (L.).

598 Intact superficial (A) and canal (B) neuromasts observed in a control fish. Superficial

599 neuromast is still covered by its cupula (A) whereas its absence on canal neuromast

600 reveals hair bundles (insert in B). The crushed appearance of superficial neuromast

601 cupula is due to a manipulation artefact. C, D. Three days after chronic cadmium

602 exposure, the majority of superficial (C) and canal (D) neuromasts appeared still intact.

603 Hair bundles present within sensory maculae were normal (insert in D). However, some

604 superficial (E) and canal (F) neuromasts were damaged: their sensory maculae

605 presented hair bundles shortened, sparse (black arrow in F) or not visible (E).

606

607 Figure 2: Scanning electron micrographs showing the effect of low-concentration

608 cadmium exposure $\left(0.5 \mu \mathrm{g} .1^{-1}\right.$ for 4 hours per day) for 8 days on tissue status of both

609 types of neuromasts of sea bass trunk lateral line at the end of exposure. The majority of

610 superficial (A) and canal (B) neuromasts presented normal morphology (insert in B):

611 their sensory maculae were similar to those observed in control fish. Nevertheless, some

612 superficial (C) and canal (D) neuromasts were damaged: their sensory maculae

613 presented hair bundles shortened, sparse (insert in D) or even not visible (C).

614

615 Figure 3: Scanning electron micrographs showing the effect of chronic low-

616 concentration cadmium exposure $\left(0.5 \mu \mathrm{g} . \mathrm{l}^{-1}\right.$ for 4 hours per day $), 15$ days after the

617 beginning of the exposure, on tis sue status of both types of neuromasts of sea bass trunk

618 lateral line. Superficial (A) and canal (B) neuromasts were usually intact. Inserts in A 
619 and B illustrate details of sensory maculae with normal hair bundles. However, some

620 superficial (C) and canal (D) neuromasts did present altered morphology. Their hair cell

621 bundles seemed to be damaged: they were shortened, sparse (insert in D) or even not 622 visible.

623

624 Figure 4: Scanning electron micrographs showing the effect of chronic low-

625 concentration cadmium exposure $\left(0.5 \mu \mathrm{g} \cdot \mathrm{l}^{-1}\right.$ for 4 hours per day) on tissue status of both

626 types of neuromasts of sea bass trunk lateral line at the end of the experiment, 21 days

627 after the beginning of exposure. Superficial (A) and canal (B) neuromasts were

628 generally intact. Inserts in A and B illustrate details of sensory maculae with normal

629 hair bund les. Nevertheless, some superficial (C) and canal (D) neuromasts did appear

630 slightly altered.

631

632 Figure 5: Average cadmium concentrations (in $\mu \mathrm{g} \cdot \mathrm{g}^{-1}$ of dry weight) in fish gills (A) and

633 scales (B) of sea bass, Dicentrarchus labrax, exposed chronically to cadmium ions (4

634 hours per day at $\left.0.5 \mu \mathrm{g} .1^{-1}\right)$ for 8 days. Vertical bars represent the standard deviation.

635

636 Figure 6: Average percentages of positive C-start escape responses caused by lateral

637 line system stimulations over consecutive days. Day zero on the x-axis corresponds to

638 the day from when fish were exposed to $0.5 \mu \mathrm{g} .1^{-1}$ cadmium. Before cadmium exposure,

639 the majority of sea bas s positively reacted to water jet. In con trast, as soon as their

640 lateral line system was exposed to low-concentration cadmium, the average positive

641 response percentage fell significan tly. This average percentage positive response

642 declined during the period of cadmium exposure ( 8 days). Then, a recovery to baseline 
643 escape behaviour percentages in response to jet stimulation was observed from the $15^{\text {th }}$

644 day after the beginning of cadmium exposure. Vertical bars represent the standard

645 deviation.

646

647 Figure 7: Summary of all results obtained in this study: cumulated percentage positive 648 escape responses of fish (continuous black line) obtained before, at 3, 8, 15 and 21 days 649 after the beginning of cadmium chronic exposure (grey box), cumulated percentages of 650 superficial (NS, white histogram) and canal neuromasts (NC, black histogram) damaged 651 and average concen trations of cadmium in fish gills (wide black dashed line) and scales 652 (narrow black dashed line). Vertical bars represent the standard deviation of average 653 cadmium concentration.

654 
Click here to download Figure: Figure 1.doc

A

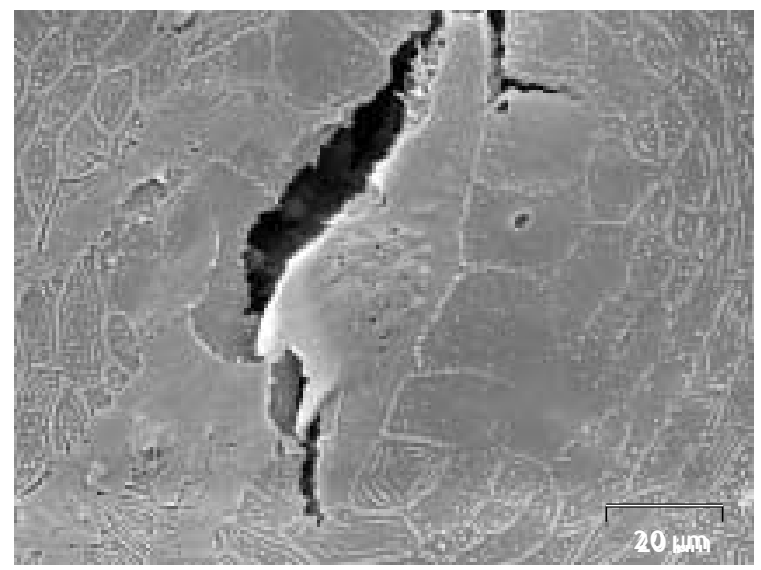

C

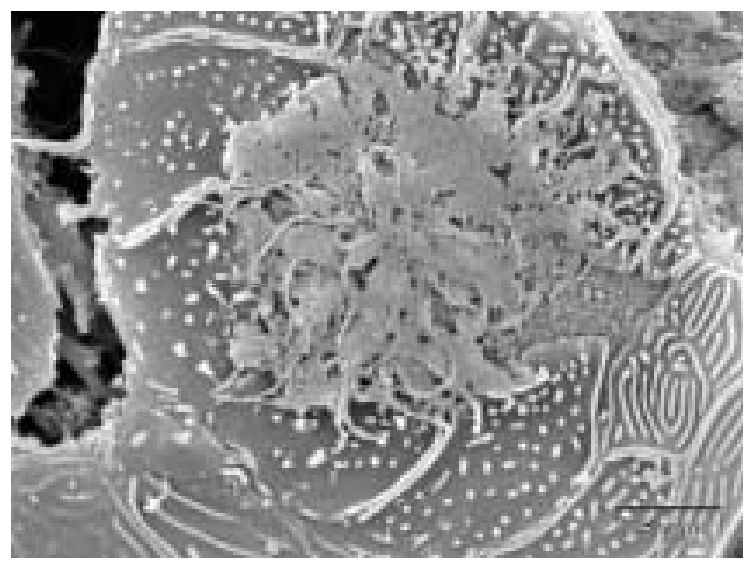

E

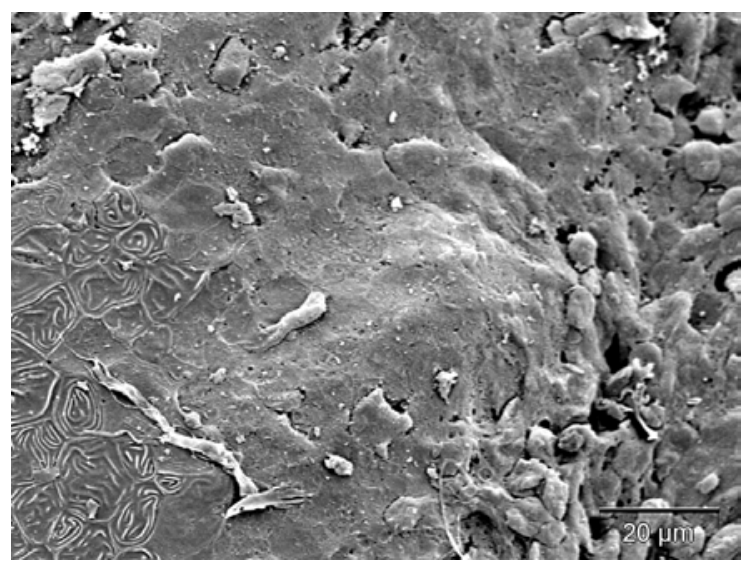

B

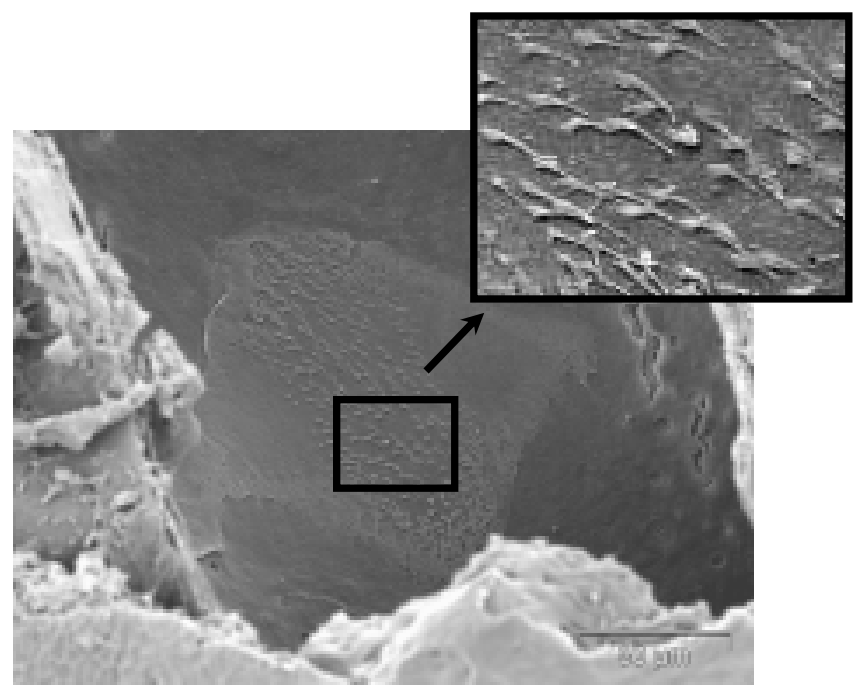

D

F

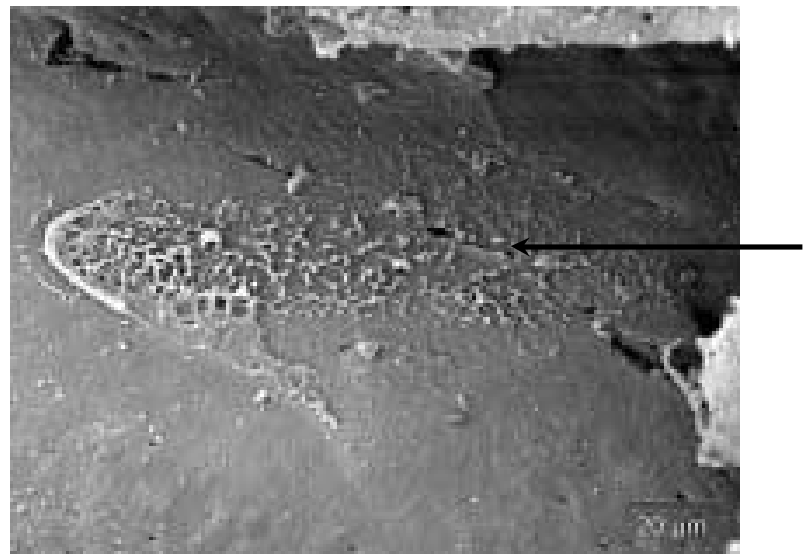


Figure 2
Click here to download Figure: Figure 2.doc

A

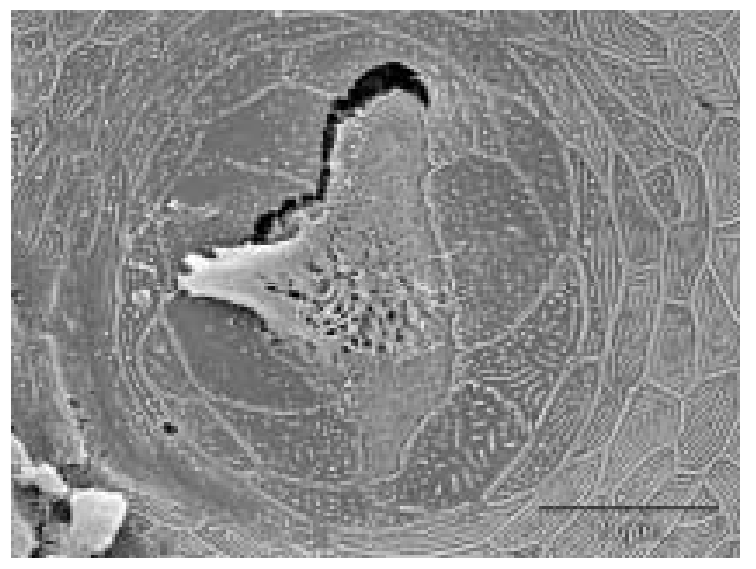

C

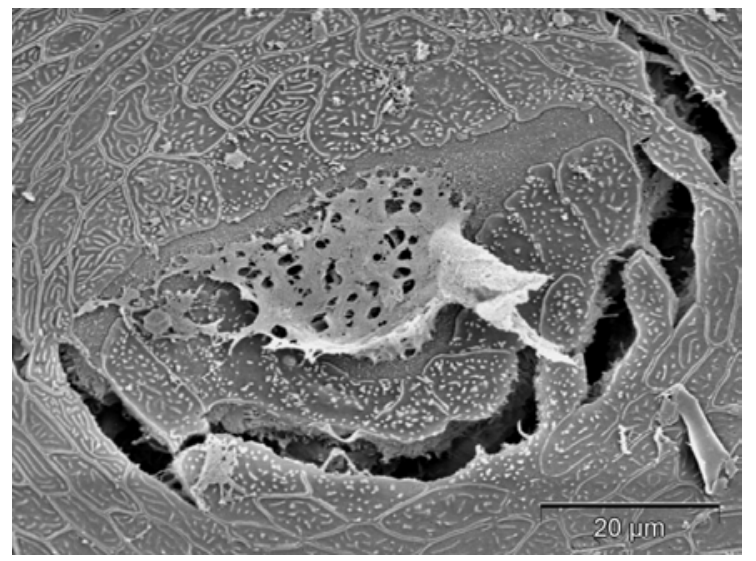

B

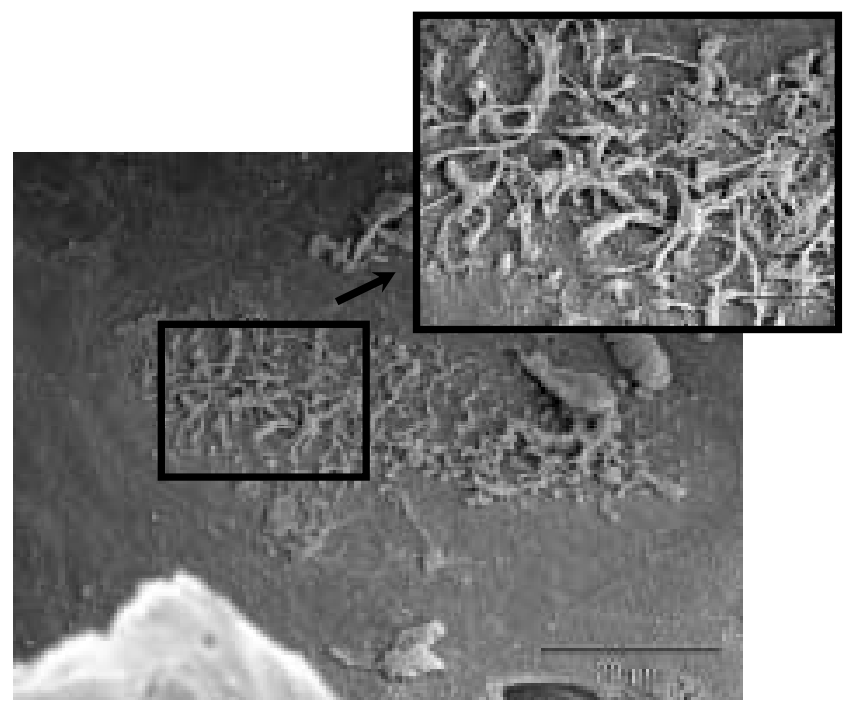

D

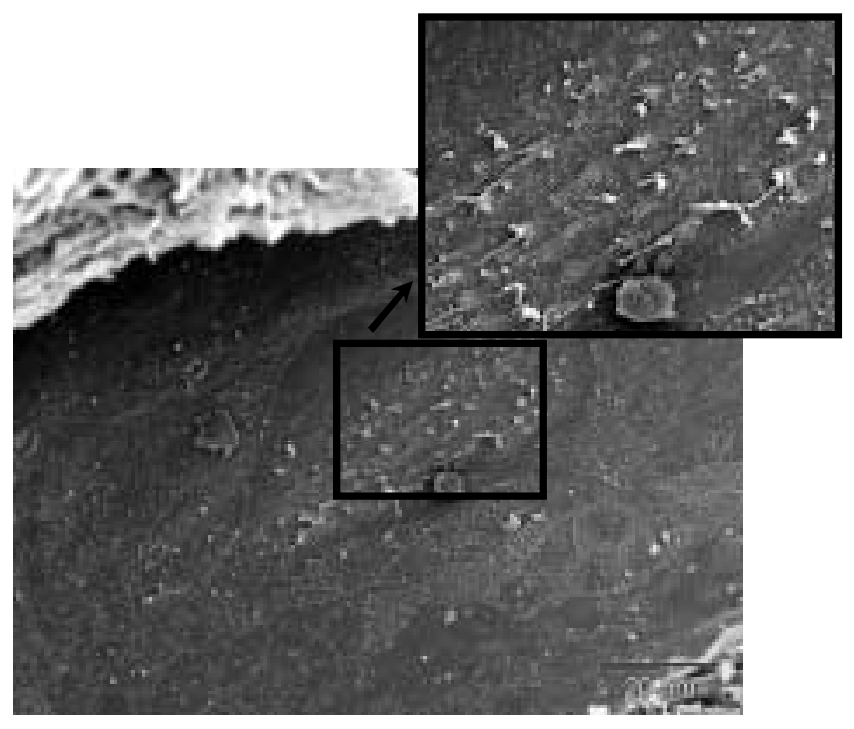


Click here to download Figure: Figure 3.doc

A

B
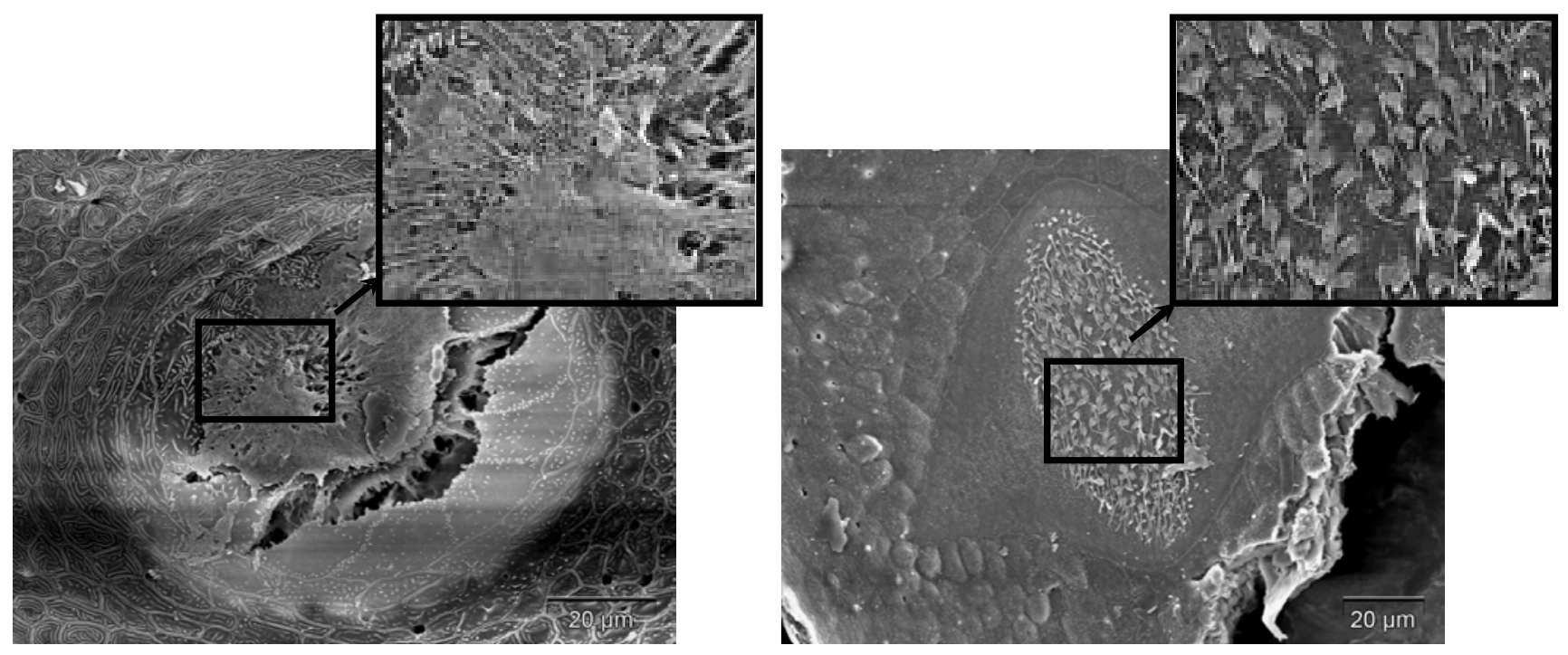

C

D
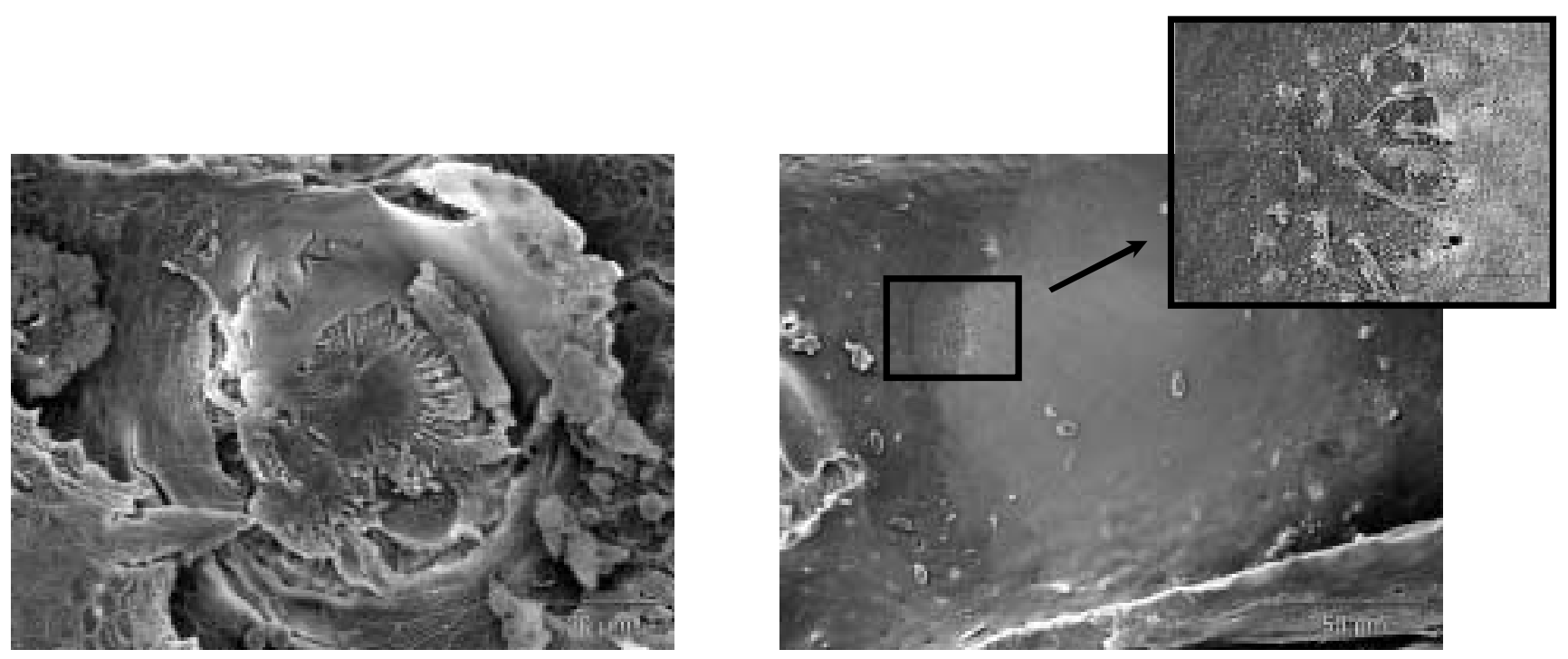
Click here to download Figure: Figure 4.doc

A

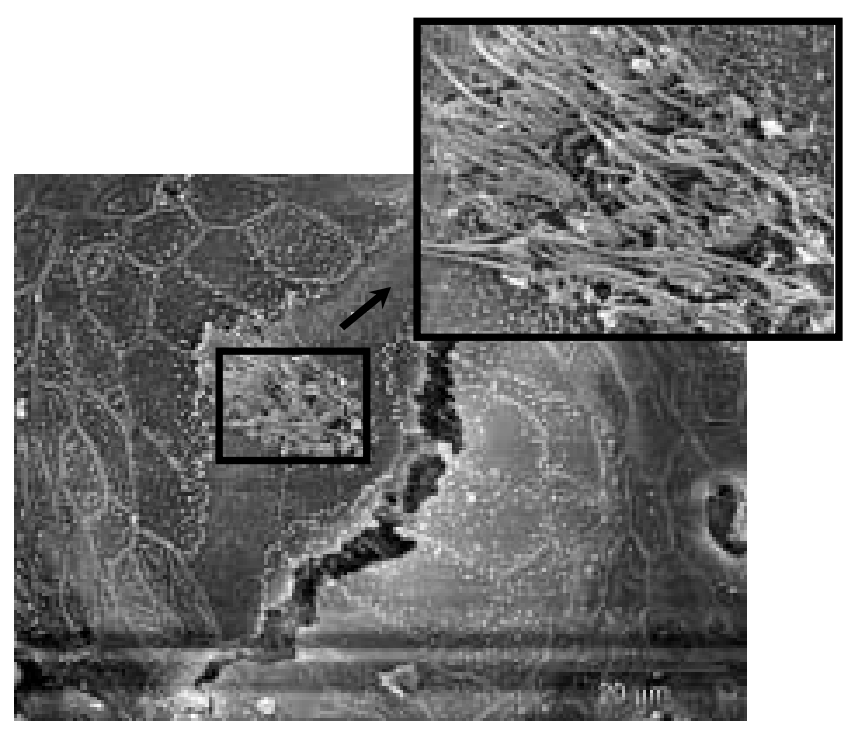

C

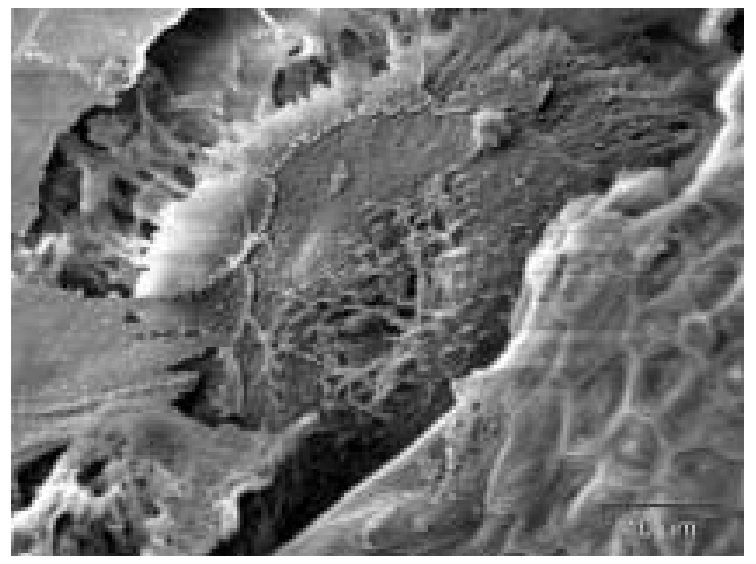

B

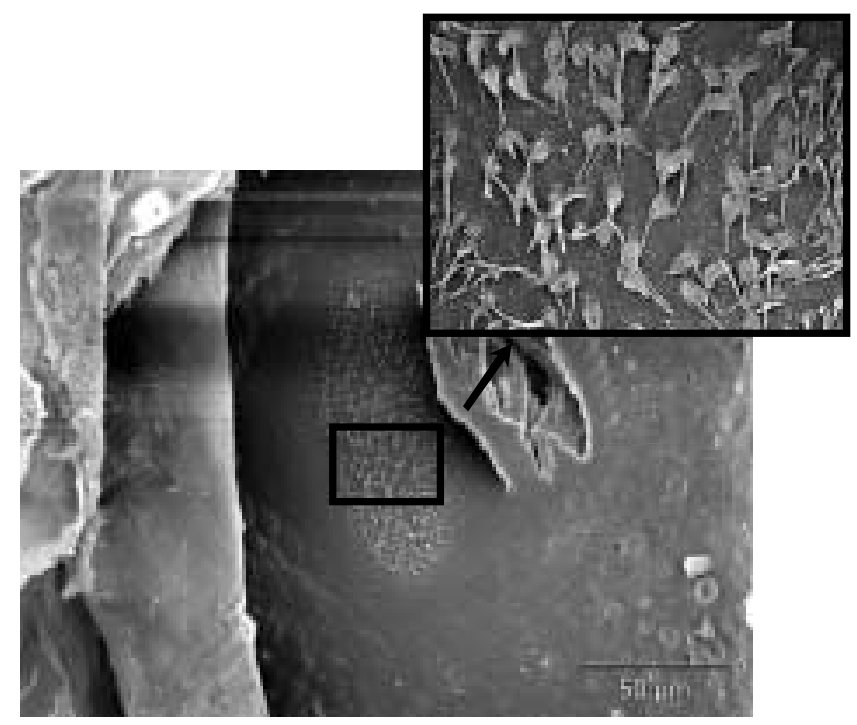

D

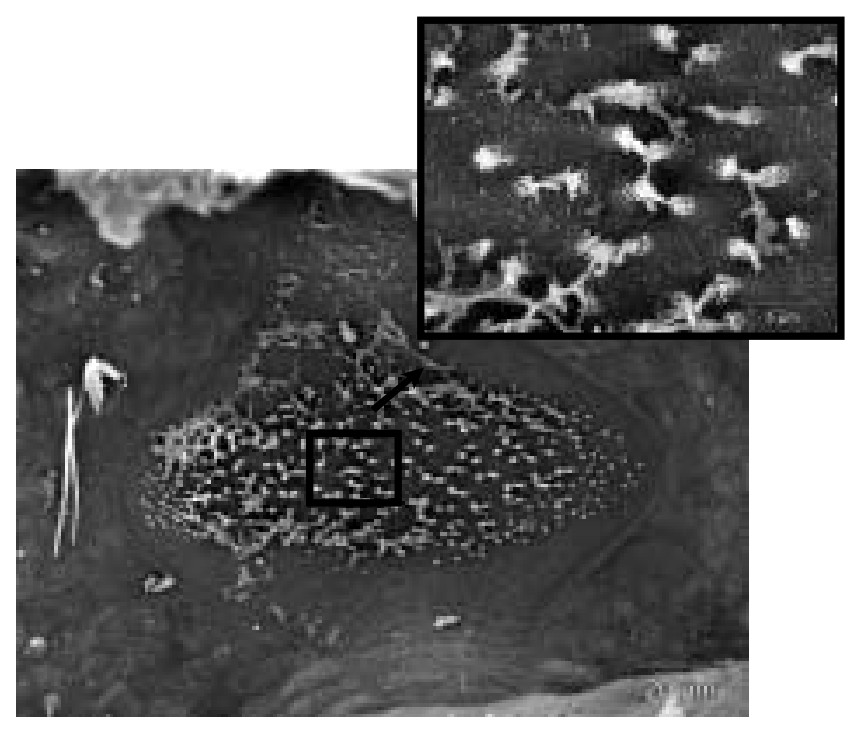




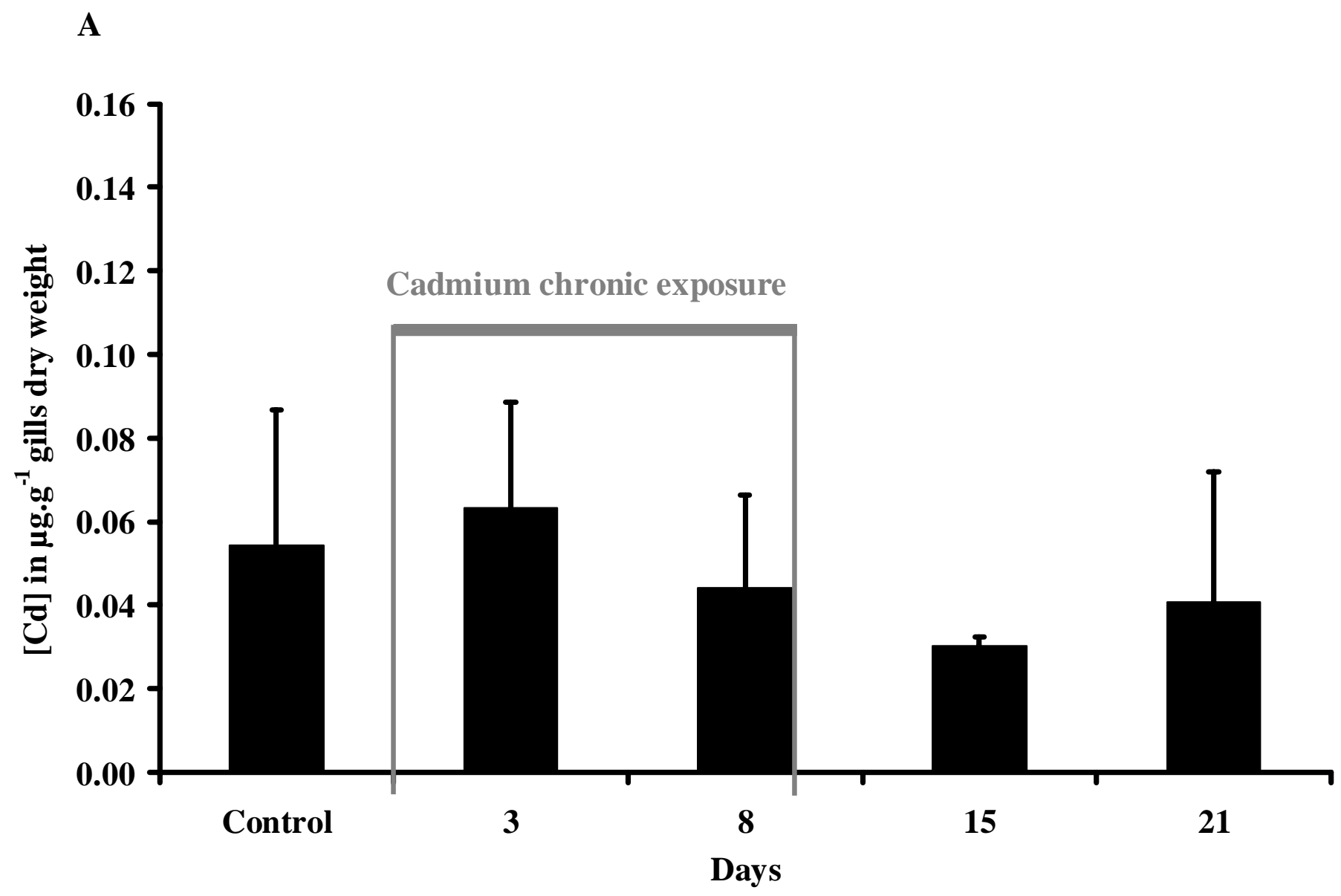

B

Cadmium chronic exposure

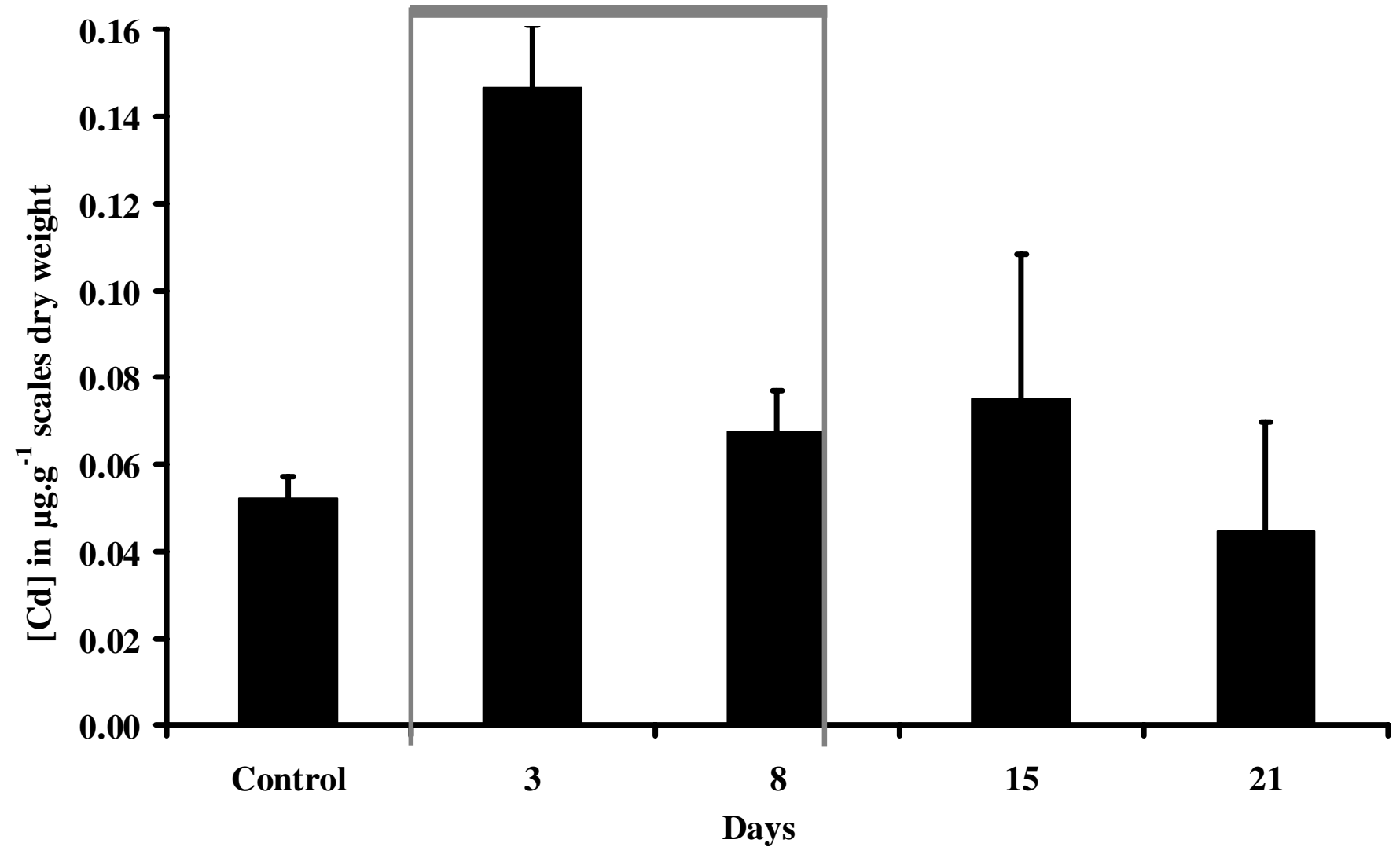




\section{Cadmium chronic exposure}

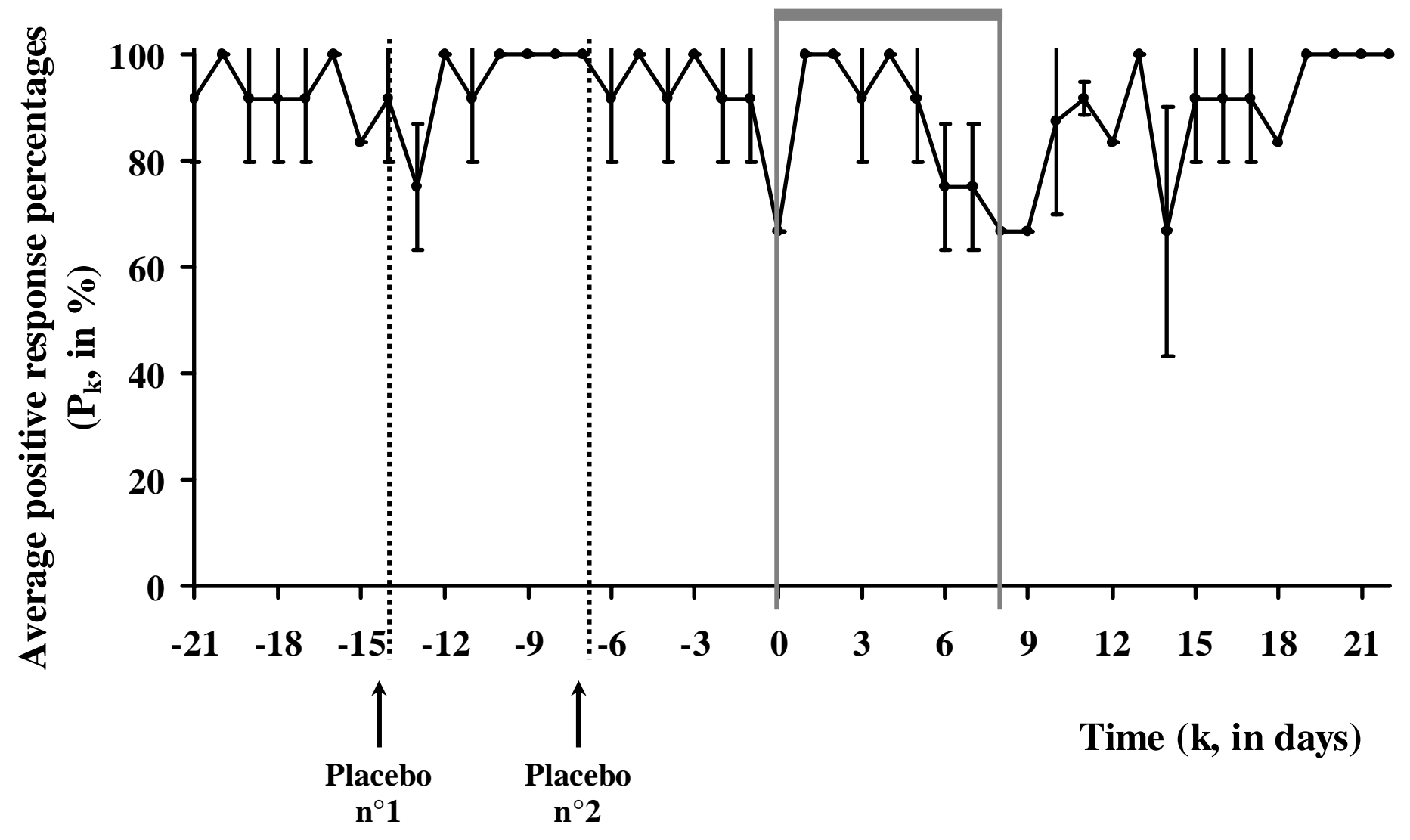




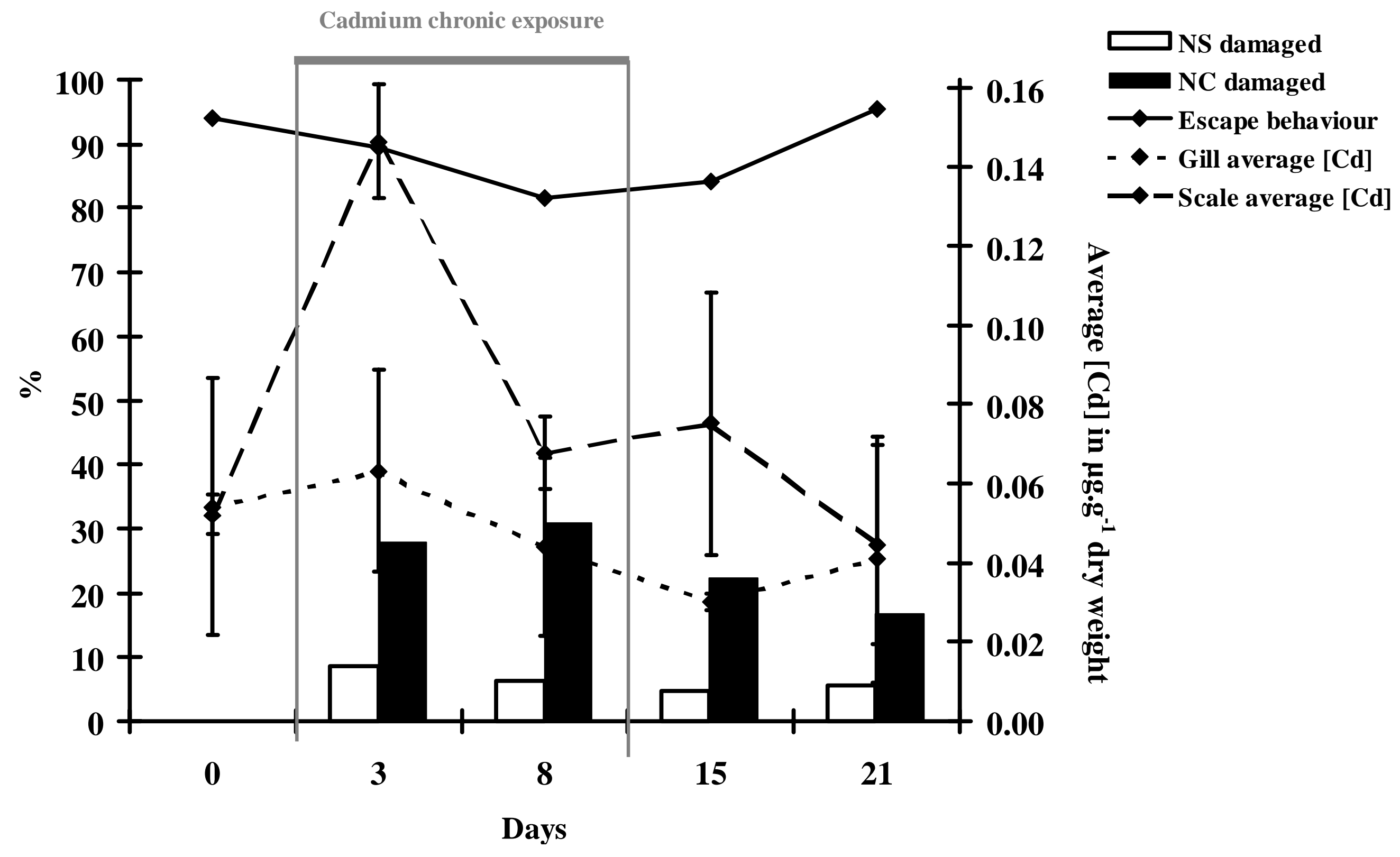

